www.readersinsight.net/APSS

\title{
DID INFORMATION ASYMMETRY, QUALITY OF AUDIT, AND INSTITUTIONAL OWNERSHIP HAVE IMPACT ON EARNINGS MANAGEMENT?
}

\section{Metta Kusumaningtyas ${ }^{\star}$}

Economics Program Doctoral, Business and Economics Faculty Diponegoro University Indonesia Accounting Department Business School of Bank BPD Jateng (STIE Bank BPD Jateng) Indonesia

\section{Anis Chariri}

Accounting Department, Business and Economics Faculty

Diponegoro University

Indonesia

\section{Etna Nur Afri Yuyetta}

Accounting Department, Business and Economics Faculty Diponegoro University

Indonesia

*Corrosponding author's Email: metta.kusumaningtyas@gmail.com

Peer-review under responsibility of $3^{\text {rd }}$ Asia International Multidisciplanry Conference 2019 editorial board (http://www.utm.my/asia/our-team/) (C) 2019 Published by Readers Insight Publisher, lat 306 Savoy Residencia, Block 3 F11/1,44000 Islamabad. Pakistan, info@ readersinsight.net This is an open access article under the CC BY-NC-ND license (http://creativecommons.org/licenses/by-nc-nd/4.0/). 


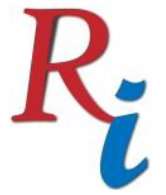

\title{
Asia Proceedings of Social Sciences
}

\author{
(APSS) \\ www.readersinsight.net/APSS
}

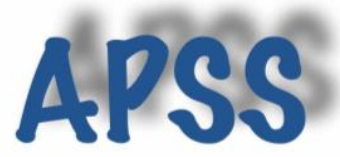

\section{Re search H i g h I igh t s}

Earnings management is very attractive to corporate stakeholders, particularly income is often regarded as predictors of accurate financial reporting quality because accounting accruals brighten the quality of the closest financial reporting (Alzoubi, 2018). Information asymmetry is an alternative part of the extent to which investors have received misinformation that is available in the company's financial statements obtained from financial markets (Wang, 2017). The amount of manipulation found depends on the quality of audit services. In addition, auditor experience, auditor's knowledge of the industry, and auditor independence greatly influence the quality of audit services. Knowledge and experience that is owned by an auditor will greatly help the auditor to diagnose complex problems in certain company industries (Habbash \& Alghamdi, 2017). The percentage of certain shares owned by the institution can influence the process of preparing financial statements that do not cover the possibility of accrualization in accordance with the interests of management (Boediono, 2005).

This study proposed four hypothesis and results indicated that audit quality has a significant and negative influence on earnings management. While institutional ownership is accepted as a moderating variable and weakens the influence of information asymmetry on earnings management. In contrast, information asymmetry does not affect earnings management and institutional ownership does not strengthen the influence of audit quality on earnings management.

\section{Research Objectives}

This study aims to investigate whether is information asymmetry, audit quality has an effect on earnings management with institutional ownership as a moderating variable.

\section{Methodology}

The research data collection consists of all mining companies listed on the Indonesia Stock Exchange (IDX) during the 2012-2016 period. This study uses the mining company sector as an object of research because the mining sector is an industry that is able to provide relatively high contribution margins for investors so that financial reports produced by companies in this sector are considered and issues are always considered by investors (Singawinata, 2007). The sample used in this study has several predetermined criteria. First, this study uses mining companies that are consistently listed on the Indonesia Stock Exchange (IDX) on January 1, 2012, until December 31, 2016. Second, companies publish financial reports for the period 2012-2016 which are available in the Indonesian Capital Market Directory (ICMD), www. idx.co.id or the company's website. Third, data on research variables are available to be completed in the company.Based on the above criteria, then in this study produced 28 companies with 5-years sample observations, the research sample used in this study was 140 samples in the year of observation.

\section{Results}

Hypothesis 1 which states that information asymmetry has a positive influence on earnings management is rejected. The result show the possibility of errors in previous financial reporting that are not in accordance with qualitative rules (Sulistyanto, 2008).

Hypothesis 2 states that audit quality has a negative effect on earnings management is accepted. The results of the research data show that if a company is audited by an audit company affiliated with Big 4, the results of the report are more qualified and can prevent earnings management 


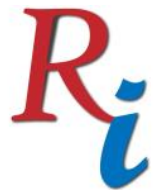

\section{Asia Proceedings of Social Sciences}

(APSS)

www.readersinsight.net/APSS

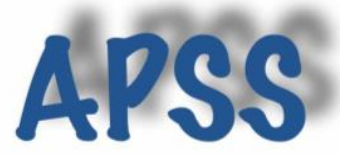

from being carried out by a manager in a company. Auditors affiliated with Big 4 are more competent and professional so they have broader and more adequate knowledge about how to detect earnings management.

Hypothesis 3 states that institutional ownership weakens the influence of information asymmetry on earnings management. Boediono (2005) said that institutional ownership has the ability to control management through an effective monitoring process so as to reduce earnings management.

Hypothesis 4 states that institutional ownership strengthens the effect of audit quality on earnings management, otherwise it is not accepted. High institutional ownership is not a factor that can improve audit quality.

\section{Findings}

Like most similar studies, this research is subject to unavoidable limitations. Although this study has attempted to use accurate and up-to-date proxies for earnings management, discretionary accruals are a standard measure of earnings management, these steps are prone to measurement errors and thus the validity of these findings depends on the accuracy of discretionary accruals as the right proxy for earnings management.

This finding has implications for researchers in the development of the audit profession and accounting by increasing auditor independence and competence and solving problems in the Indonesian capital market.

\section{Acknowledgement}

This research work is supported by Indonesia Endowment Fund for Education of the Ministry of Finance Republik Indonesia (LPDP Indonesia).

\section{References}

Alzoubi, E. S. S. (2018). Audit Quality, Debt Financing, and Earnings Management: Evidence from Jordan. Journal of International Accounting, Auditing and Taxation, 30, 69-84. http://doi.org/10.1016/j.intaccaudtax.2017.12.001

Boediono, G. S. (2005). Kualitas Laba: Studi Pengaruh Mekanisme Corporate Governance dan Dampak Manajemen Laba dengan Menggunakan Analisis Jalur. In Simposium Nasional Akuntansi VIII. Solo.

Habbash, M., \& Alghamdi, S. (2017). Audit Quality and Earnings Management in Less Developed Economies : The Case of Saudi Arabia. Journal of Management \& Governance, 21(2), 351-373. http://doi.org/10.1007/s10997-016-9347-3

Singawinata, I. P. (2007). The Future of The Indonesian Mining Industry: Recommendations to Policy Makers. Ritsumeikan of Journal Asia Pacific Studies, 3, 99-113.

Sulistyanto, S. (2008). Manajemen Laba: Teori dan Model Empiris. Jakarta: PT. Gramedia Widiasarana Indonesia.

Wang, L. H. (2017). Accounting Quality and Information Asymmetry of Foreign Direct Investment Firms. Research in International Business and Finance, 42, 950-958. http://doi.org/10.1016/j.ribaf.2017.07.029 